\title{
Independent Redistricting Commissions and Electoral Competition in the US House of Representatives
}

\author{
James de Vault \\ Department of Economics, Lafayette College, Easton, Pennsylvania, USA \\ Email: devaultj@lafayette.edu
}

How to cite this paper: de Vault, J. (2019). Independent Redistricting Commissions and Electoral Competition in the US House of Representatives. Open Journal of Political Science, 9, 1-16. https://doi.org/10.4236/ojps.2019.91001

Received: October 8, 2018

Accepted: November 6, 2018

Published: November 9, 2018

Copyright $\odot 2019$ by author and Scientific Research Publishing Inc. This work is licensed under the Creative Commons Attribution International License (CC BY 4.0).

http://creativecommons.org/licenses/by/4.0/

\begin{abstract}
This paper analyzes whether redistricting commissions impact electoral competition in the US House of Representatives. Data from the last three redistricting cycles are used to estimate a fixed-effects regression model that controls for state and time invariant effects. The model shows that independent redistricting commissions enhance electoral competition and that this effect has become stronger since the introduction of these commissions in Arizona and California. The model also shows that other types of redistricting commissions as a whole produce districts that are no more competitive than those produced by partisan-controlled legislative redistricting.
\end{abstract}

\section{Keywords}

Electoral Competition, Redistricting Commissions

\section{Introduction}

In 2016, the Florida Supreme Court found that Florida's state legislature had failed to comply with the requirements of Florida's Fair Districts Amendment and ordered the state to redraw its congressional districts. ${ }^{1}$ In 2017, the United States Supreme Court ruled that North Carolina had engaged in an unconstitutional gerrymander and ordered the state to redraw its congressional districts. ${ }^{2}$ Both cases involved the "packing" of minorities into a small number of districts in order to dilute their voting power. Lastly, in 2018 the US Supreme Court heard a case involving Maryland where it was alleged that a Republican congressional seat was eliminated by "cracking" Republican voters in the original dis2017. 
trict across several surrounding districts in a way that essentially guaranteed Democrats would win all the newly drawn districts. ${ }^{3}$

At issue in all of these cases was the practice of gerrymandering, whereby a political party redraws political boundaries in such a way as to enhance or solidify its own political representation. Gerrymandering has been practiced in the United States almost since its inception but in recent years the practice has come under increased scrutiny. This is because the introduction of new mapping technologies has made it possible to draw political boundaries at a much higher level of granularity than in the past. As a consequence, it is now possible to conduct gerrymandering much more effectively, which has in turn increased the costs associated with it. These costs include the weakening of democracy and the deepening of partisanship (Mann, 2016). Democracy is weakened by gerrymandering because gerrymandering is more likely to produce situations in which a party's political representation is at odds with the will of voters. For example, in Michigan's 2012 congressional elections, Republican candidates received just 46 percent of the votes cast but won 64 percent of the congressional seats at stake as a result of an aggressive redistricting plan. Partisanship is increased as a result of gerrymandering in part because it intensifies party competition for control of the redistricting process and in part because gerrymandered districts are often more politically extreme, particularly when one party's voters are packed into a single or small number of districts.

Because the costs of gerrymandered appear to have increased over the last several decades, calls for reforming redistricting processes have grown significantly during this period. In response, a small but growing number of states have undertaken redistricting reforms and many others are considering such reforms. The most widely adopted redistricting reform involves the introduction of a redistricting commission, as in states like Arizona, California, Hawaii, Idaho, Iowa, New Jersey and Washington. Other redistricting reforms that have been undertaken or are being considered include the introduction of explicit redistricting criteria (as seen most recently in Florida), the use of ranked-choice voting (recently introduced in Maine) and the adoption of multi-member districts.

In this paper, I analyze the impact of redistricting commissions because these commissions have been used frequently and over an extended period of time. My goal in the paper is to measure the effect of redistricting commissions on electoral competition in the US House of Representatives. Prior work in this area (McDonald, 2006; Lublin \& McDonald, 2006; Yoshinka \& Murphy, 2011; Winburn, 2011; Masket, Winburn, \& Wright, 2012; Carson, Crespin, \& Williamson, 2014) has produced conflicting results, with some studies finding pro-competitive effects and others finding little if any effect.

My work in this paper is distinguished from almost all previous work in this area because it employs a different measure of electoral competition, one that I

${ }^{3}$ Benisek v. Lamone, 585 U.S. (2018). 
believe better reflects the impact of redistricting than more conventional measures. The measure I use is the district normalized presidential vote (Abramowitz et al., 2006), which is the difference between the Democratic share of the major party presidential vote for a district and the Democratic share of the major party presidential vote for the nation. This measure of electoral competition has two important advantages over more commonly-used measures. First, the district normalized presidential vote (DNPV) is continuous, unlike the binary dependent variable employed in many other studies of electoral competition, including Carson, Crespin and Williamson (2014), the work to which this paper is most closely linked. When a binary dependent variable is employed, districts are deemed either competitive or safe depending on whether the winner's share of the major party vote in a district falls above or below some arbitrary cutoff point. Thus if the cutoff is 60 percent, then all districts with a winning share less than 60 percent are considered competitive while all those at or above 60 percent are not. The problem with an arbitrary cutoff is that it is not sufficiently granular. For example, are elections in which the winning candidate receives 59 percent of the major party vote really that much more competitive than those in which the winning candidate receives 60 percent to justify a distinction between the two? Similarly, aren't elections in which the winning candidate receives 51 percent of the major party vote sufficiently more competitive than those in which the winning candidate receives 59 percent to justify a distinction between the two? The use of a continuous dependent variable, such as the DNPV, solves this problem.

The second advantage of the DNPV is that its value depends on the results of presidential elections, not candidate-specific elections. This means that the DNPV is independent of the characteristics of the House candidates themselves. This greatly simplifies the analysis since factors like incumbency status, campaign finance and the personal vote no longer have to be controlled for in order to isolate the effect of redistricting. All of these measures need to be controlled for when the results from candidate-specific elections are used to gauge competitiveness, making it much more difficult to isolate the effect of redistricting when these results are used instead of the DNPV.

In what follows, I briefly discuss the nature of redistricting processes, both in theory and in practice. I then provide some preliminary measures of competitiveness in US House elections before moving on to conduct a fixed-effects regression analysis that is used to identify the effect of redistricting commissions on competitiveness.

\section{Redistricting in Theory}

Much of the theoretical work on redistricting focuses on the concept of an optimal gerrymander. ${ }^{4}$ All of the theoretical analysis of gerrymandering assumes that redistricting is conducted exclusively by the majority party and that the primary goal is to redistrict in such a manner as to maximize the majority par-

${ }^{4}$ Exceptions include Coate and Knight (2007), Besley and Preston (2007), and Bracco (2013). 
ty's seat share. Earlier models of optimal gerrymandering that are not micro-founded (Owen \& Grofman, 1988; Sherstyuk, 1998) find that the optimal gerrymander "packs" voters of the minority party into a relatively small number of districts. A more recent study of the optimal gerrymander that is micro-founded (Friedman \& Holden, 2008) reaches a very different conclusion. This study assumes that voter preferences are noisy and finds that the optimal gerrymander generally involves a "matching slices" approach where majority and minority party voters are paired in districts according to the intensity of their party support, with an appropriately sized buffer favoring the majority party. Thus the majority party's most ardent supporters should be paired with the most ardent supporters of the minority party in order to most effectively neutralize the latter. In this model, the level of competition is greater than in earlier models because minority party voters are no longer packed into a small number of districts. This does not imply that the majority party wins fewer seats, however. Indeed, because the majority party concedes no seats to the minority party, it is likely to gain an even larger seat majority.

The results from these models must be adjusted to account for a number of constraints that limit the ability of a legislature to implement the optimal gerrymander. First, the geographical dispersion of voters, when combined with criteria such as contiguity and compactness, can block the optimal gerrymander. Second, legislation such as the US Voting Rights Act of 1965 can also impede the optimal gerrymander. Finally, the willingness of incumbents to passively submit to the optimal gerrymander is also questionable. In short, even in the case in which the majority party has complete control of the redistricting process, its ability to enact the optimal gerrymander is constrained by a number of factors.

Theory has little to say about redistricting plans produced by bipartisan legislatures, redistricting commissions, or the courts. The next section examines how redistricting has been conducted by each of these bodies in practice.

\section{Redistricting in Practice}

In practice, congressional redistricting is conducted by one of three bodies: the state legislature, the courts, or a redistricting commission. When state legislatures are responsible for redistricting, members of the legislature develop a redistricting plan which typically must be approved by the governor. Redistricting plans produced by state legislatures can be either partisan or bipartisan, depending on whether control of the legislature and the governorship is unified under one party or split between parties. Partisan redistricting plans, as noted above, are generally designed to maximize the seat share of the majority party. In contrast, bipartisan redistricting plans are often designed to minimize the competitive threat to incumbents. So-called incumbent protection plans are often argued to have a more adverse effect on competitiveness than partisan redistricting plans as a consequence. Not all bipartisan redistricting plans protect 
incumbents, however, and even when they do, it is not clear that competition is reduced more than under a partisan redistricting plan.

Redistricting by the courts usually occurs when a legislative redistricting plan does not satisfy certain legal criteria, such as the Voting Rights Act, or when the legislature is deadlocked and cannot put forth a plan. The exact effect of court-based redistricting depends upon how it is carried out. In some cases, the judiciary is reluctant to usurp legislative authority over redistricting and puts forth plans that modify existing districts by as little as possible in order to satisfy legal requirements such as equal population and the Voting Rights Act. In other cases, courts may appoint Special Masters and give them greater latitude, as was the case in California during the 1970 and 1990 redistricting cycles and Connecticut in the 2010 cycle. In still other cases, the courts may select among competing plans put forth by a deadlocked legislature. Several studies (Cottrill \& Peretti, 2013; Carson, Crespin, \& Williamson, 2014) find that judicial redistricting produces greater competition in congressional elections than legislative redistricting.

The impact of redistricting commissions on competitiveness hinges on several factors, the most important of which is the degree of a commission's independence from the legislature (Cain, 2012). Two factors are particularly relevant here. The first factor is whether a commission is fully vested with the authority to design and implement a redistricting plan. In Arizona, California, Idaho and Washington, commissions have this authority. Backup commissions in Connecticut and Indiana may also be granted this authority, but only if the legislature fails to enact a redistricting plan. In contrast, commissions in Iowa, Maine Maryland, New York, Rhode Island and Virginia serve in an advisory capacity and legislatures in these states are free to adopt, modify or ignore the redistricting plans of these commissions. The second factor is whether commissions have elected officials as members. Redistricting commissions that do not preclude elected officials as members, such as those of Connecticut, Hawaii, Indiana and New Jersey, are less independent and are referred to as political commissions as a result. In contrast, elected officials are precluded from serving on redistricting commissions in Arizona, California, Idaho and Washington.

Even when redistricting commissions are independent, however, there is no guarantee that the plans they produce will be more competitive than those produced by legislatures or the courts. Much depends on the criteria under which commissions operate as well as the geographic distribution of voters within a state. Traditional redistricting criteria such as compactness, contiguity, and the integrity of political subdivisions may conflict with one another, making it hard for commissions to satisfy all such criteria simultaneously. The geographic segregation of voters from different parties, especially along urban and rural lines, may also produce lopsided districts that are not representative of the overall distribution of a state's voters. And commissions are also bound by the Voting Rights Act, just as are legislatures and the courts. 


\section{Trends in the Competitiveness of House Elections}

In this section, I examine recent trends in district competitiveness using actual victory margins and the district normalized presidential vote (Abramowitz et al., 2006). Table 1 shows the competitiveness of House races based on these measures for all congressional elections held in 1996, 2000, 2004, 2008, 2012 and 2016. I focus on presidential election years because the district normalized presidential vote is only available in these years. It's worth noting that the data cover two elections for each of the last three redistricting cycles.

Consider first measures based on actual victory margins. I start by computing the share of the major party vote received by each major party House candidate. ${ }^{5}$ I then use these shares to compute the mean victory margin for all winning candidates. ${ }^{6}$ Table 1 shows that the mean victory margin increased irregularly from 16.3 percentage points in the 1996 election to 20.6 percent age points in the 2016 election, suggesting that competitiveness decreased during this period. Note however that highest mean victory margin was 21.7 percentage points and was recorded in the 2000 election.

Another way to view the data involving actual victory margins is to classify districts based on the size of the victory margin. I classify a district as "competitive" if the absolute difference between the major party vote shares of the Democratic and Republican congressional candidates is less than ten percentage points. Districts are considered "safe" if the absolute victory margin is greater than twenty percentage points. Using this classification scheme, Table 1 shows that the percentage of competitive districts fell irregularly from 17.7 percent in the 1996 election to 7.4 percent in the 2016 election. In contrast, the percentage of safe districts rose irregularly from 65.3 percent in the 1996 election to 75.4 percent in the 2016 election. Both changes suggest a decline in competitiveness.

Table 1. District competitiveness.

\begin{tabular}{|c|c|c|c|c|c|c|}
\hline & 1996 & 2000 & 2004 & 2008 & 2012 & 2016 \\
\hline \multicolumn{7}{|l|}{ By actual election results } \\
\hline Mean victory margin & 16.3 & 21.7 & 21.5 & 19.8 & 18.3 & 20.6 \\
\hline Percentage of competitive districts & 17.7 & 9.7 & 5.1 & 11.5 & 14.0 & 7.4 \\
\hline Percentage of safe districts & 65.3 & 78.2 & 83.0 & 72.9 & 67.4 & 75.4 \\
\hline \multicolumn{7}{|l|}{$\begin{array}{l}\text { By the district normalized } \\
\text { presidential vote }\end{array}$} \\
\hline Mean victory margin & 10.0 & 11.2 & 11.6 & 12.0 & 13.3 & 14.7 \\
\hline Percentage of competitive districts & 30.6 & 28.0 & 25.1 & 25.5 & 19.3 & 15.6 \\
\hline Percentage of safe districts & 39.5 & 45.3 & 48.0 & 49.9 & 57.5 & 61.8 \\
\hline
\end{tabular}

${ }^{5}$ All data are taken from the Almanac for American Politics.

${ }^{6}$ In races contested by only one major party candidate, the victory margin is recorded as 100 percent. In races contested by two major party candidates from the same party, the victory margin is also recorded as 100 percent. Winning candidates who are independent are classified as Democratic or Republican depending on the party they caucus with. 
The second measure of competitiveness I use is based on the district normalized presidential vote (DNPV). The DNPV gives the difference between the Democratic share of the major party presidential vote for a district and the Democratic share of the major party presidential vote for the nation. As Abramowitz et al. (2006) point out, the DNPV is "comparable across districts and elections and independent of the results of congressional elections themselves." The latter is particularly important because it implies that the DNPV is independent of a House candidate's incumbency status and campaign contributions. As such, the DNPV better reflects the impact of congressional redistricting on competitiveness than actual election results, which depend on a much wider set of determinants. The DNPV is also well defined for all congressional races, including races that are uncontested as well as races in which two candidates from the same party face off in the general election.

Because the DNPV can be positive or negative, I use the absolute value of the DNPV to measure competitiveness rather than the actual value. This transformation insures that greater values of the DNPV are associated with less competitive elections, which would not be the case otherwise. Adjusted for this transformation, the mean DNPV shows a clear pattern of declining competitiveness across the six elections, rising monotonically from 10 percentage points in the 1996 election to 14.7 percentage points in the 2016 election. Using the same classification scheme employed above, I find that the percentage of competitive districts fell by 15 percentage points between 2000 and 2012 while the percentage of safe districts increased by 22 percentage points. In short, the DNPV show a clear decline in the competitiveness of US House elections across the observation period.

Based on the data in Table 1, it is clear that the competitiveness of House elections has declined since 1996. To what extent, however, is this decline in competitiveness the result of gerrymandering? And to what extent might the introduction of redistricting commissions be expected to restore competitiveness? To answer these two questions, I now estimate a fixed effects regression model that allows me to control for other factors that might impact competitiveness during the observation period.

\section{Fixed-Effects Regression Analysis}

Because the regression analysis is designed to estimate the effect of redistricting on competitiveness, an appropriate measure of competitiveness must first be identified. Previous work has often been based on a binary dependent variable whose value depends on whether a district is deemed safe or competitive (Carson \& Crespin, 2004; Jacobson, 2013; Carson, Crespin, \& Williamson, 2014). While a binary dependent variable has certain advantages, it suffers from some obvious weaknesses, as was noted in the introduction to this paper. To address these weaknesses, I use the DNPV instead. As noted earlier, the DNPV is a continuous variable that is independent of the characteristics of the congressional 
candidates themselves, both of which make it easier to pinpoint the effect of redistricting. It is also worth pointing out that in the elections considered here, the correlation coefficient between the winner's share of the major party vote and the DNPV was 0.71. This high degree of correlation, when combined with the other advantages of the DNPV, make it a superior measure of electoral competitiveness. Because I use the absolute value of a district's DNPV as the dependent variable, the greater the dependent variable, the less competitive the election.

I limit my attention to a handful of independent variables, including partisan bias at the state level, preclearance requirements under the Voting Rights Act, and a series of indicator variables designed to capture the effects of redistricting. Partisan bias at the state level is captured by the absolute value of the difference between the share of the major party vote won by the Democratic presidential candidate at the state level and the share won at the national level. To distinguish this difference from the DNPV, I call it the state normalized presidential vote (SNPV). Increases in the SNPV mean that a state's electorate is becoming more partisan relative to the national electorate, implying that its congressional districts as a whole should also become more partisan. This in turn implies a higher average DNPV across the state's congressional districts.

SNPV is designed to capture the impact that geographic sorting has on the competitiveness of a state's congressional races (Chen \& Rodden, 2013). Two examples demonstrate this point. Consider the states of Iowa and Kansas in 2012. In Iowa, the SNPV in 2012 was roughly one percentage point and the average DNPV was roughly four percentage points, showing that House races in Iowa were competitive in large part because the state's electorate was close to non-partisan. In contrast, in Kansas the SNPV in 2012 was roughly thirteen percentage points and the average DNPV was nearly fourteen percentage points. Clearly the Kansas electorate was highly partisan in 2012 and as a consequence, House races in Kansas were not competitive.

The second explanatory factor is the preclearance requirement of the Voting Rights Act of 1965. Prior to June 25, 2013, when the Supreme Court effectively struck it down, Section 5 of the Voting Rights Act required states that included "covered jurisdictions" to submit all changes in voting practices (including redistricting plans) to the Department of Justice for preclearance to insure that they did not have a discriminatory effect. Covered jurisdictions referred to states, counties or municipalities with a prior record of voting practices that were deemed discriminatory. The preclearance requirement, when combined with changes in the Voting Rights Act in 1982, led to the emergence of so-called majority-minority districts, or districts in which minorities compromise at least half of the electorate. These districts typically vote overwhelmingly for Democratic candidates and hence are rarely competitive. The adverse effect of the preclearance requirement on competition doesn't end there however. Because majority-minority districts are often produced by packing minority voters into a relatively small number of districts, the surrounding districts become substantially 
more Republican and hence less competitive, a fact Republicans have allegedly used to their advantage (Washington, 2011).

To incorporate the effect of preclearance on electoral competitiveness, an indicator variable is used to identify states subject to preclearance. This variable takes a value of one if the state is subject to preclearance and a value of zero if not. $^{7}$ If the preclearance requirement does adversely impact electoral competition, then the coefficient on the preclearance indicator variable should be positive, so that states subject to this requirement have a higher DNPV than states that are not subject to it, other things equal.

To examine the impact of redistricting on electoral competition for House seats, I introduce four indicator variables that serve to identify the body responsible for conducting redistricting. These indicators variables cover redistricting controlled by bipartisan legislatures, by the courts, by independent redistricting commissions and by other forms of commissions, including political, advisory and backup commissions. ${ }^{8}$ Redistricting conducted by partisan legislatures is the excluded category, so coefficient estimates for the other indicators variables indicate the difference with respect to partisan legislative redistricting. In addition to the other independent variables, I also include state and year fixed effects. These fixed effects control for state-invariant and time-invariant omitted variables.

The sample used to conduct the regression analysis is drawn from the 1996, 2000, 2004, 2008, 2012 and 2016 national elections. I choose these elections because the DNPV and SNPV are not defined for midterm elections. The original sample includes 2610 observations, but observations for the seven at-large states are dropped for each election, reducing the number of observations to 2568 . District and state normalized presidential votes are calculated using data from the Almanac of American Politics. The preclearance variable is derived from data provided by the US Department of Justice. 9 To determine the redistricting process employed by a particular state in a particular election, I use a variety of sources ${ }^{10}$. The Appendix lists the redistricting process used by each state in each election.

Regression results for six model specifications are presented in Table 2 with standard errors clustered by state and fixed effects suppressed. The first three

\footnotetext{
${ }^{7}$ The states covered by the preclearance requirement during the observation period were Alabama, Alaska, Arizona, California, Florida, Georgia, Louisiana, Michigan, Mississippi, New York, North Carolina, South Carolina, South Dakota, Texas and Virginia (https://www.justice.gov/crt/jurisdictions-previously-covered-section-5). Note that the entire redistricting plan of a state is subject to preclearance even if the covered jurisdiction is a political subdivision within the state.

${ }^{8}$ I exclude advisory commissions that include legislators or other elected officials as such commissions are essentially an extension of the legislature or the governor. Based on this criteria, only Iowa's Legislative Service Agency is considered an advisory commission. ${ }^{9}$ https://www.justice.gov/crt/jurisdictions-previously-covered-section-5.

${ }^{10}$ All About Redistricting, (http://redistricting.lls.edu/2010districts.php), Ballotpedia. (http://ballotpedia.org/State-by-state_redistricting_procedures, Cain, 2012, Fairvote. (http://archive.fairvote.org/index.php?page=289) and McDonald, 2004.
} 
specifications present coefficient estimates for a model containing just two independent variables, the SNPV and the preclearance indicator. The first specification in this group includes all states with at least two congressional districts, the second includes all states with at least five congressional districts and the third includes all states with at least nine congressional districts. I vary the number of congressional districts in this way because states with more congressional districts have greater latitude with regards to how redistricting is conducted, so the importance of both the preclearance requirement and the redistricting procedure may increase as the number of congressional districts rises.

As hypothesized, the coefficient on the SNPV is positive, implying that greater partisanship at the state level leads to less competitive races, hardly a surprising result. This coefficient is statistically significant at conventional levels and its value implies that a ten percentage point increase in the SNPV leads to about a four percentage point increase in the DNPV. The coefficient on the preclearance indicator is also positive as hypothesized, implying that the preclearance requirement reduces electoral competition as measured by the DNPV. This coefficient is statistically at conventional levels and its value implies that the presence of the preclearance requirement produces a little bit less than a two percentage point increase in the DNPV. Neither the coefficient on the SNPV nor the coefficient on the preclearance requirement appears to change much as the minimum number of congressional districts rises.

Table 2. Regression results for 1996-2016 presidential elections (clustered standard errors in parentheses, state and year fixed effects suppressed)

\begin{tabular}{|c|c|c|c|c|c|c|}
\hline & Model 1 & Model 2 & Model 3 & Model 4 & Model 5 & Model 6 \\
\hline $\begin{array}{l}\text { State normalized } \\
\text { presidential vote } \\
\text { (SNPV) }\end{array}$ & $\begin{array}{l}0.3913^{* *} \\
(0.0845)\end{array}$ & $\begin{array}{l}0.3791^{* *} \\
(0.0901)\end{array}$ & $\begin{array}{l}0.4269^{* *} \\
(0.1009)\end{array}$ & $\begin{array}{l}0.3950^{\star *} \\
(0.0870)\end{array}$ & $\begin{array}{l}0.3838^{* *} \\
(0.0928)\end{array}$ & $\begin{array}{l}0.4355^{* *} \\
(0.1040)\end{array}$ \\
\hline $\begin{array}{c}\text { Preclearance indicator } \\
\text { variable }\end{array}$ & $\begin{array}{l}0.0151^{* *} \\
(0.0047)\end{array}$ & $\begin{array}{l}0.0178^{* *} \\
(0.0052)\end{array}$ & $\begin{array}{l}0.0152^{\star} \\
(0.0059)\end{array}$ & $\begin{array}{l}0.0177^{\star *} \\
(0.0046)\end{array}$ & $\begin{array}{l}0.0210^{* *} \\
(0.0051)\end{array}$ & $\begin{array}{l}0.0197^{* *} \\
(0.0054)\end{array}$ \\
\hline $\begin{array}{l}\text { Bipartisan legislative } \\
\text { indicator variable }\end{array}$ & - & - & - & $\begin{array}{l}-0.0008 \\
(0.0054)\end{array}$ & $\begin{array}{l}-0.0007 \\
(0.0059)\end{array}$ & $\begin{array}{l}-0.0012 \\
(0.0058)\end{array}$ \\
\hline $\begin{array}{c}\text { Judicial } \\
\text { indicator variable }\end{array}$ & - & - & - & $\begin{array}{c}0.0023 \\
(0.0035)\end{array}$ & $\begin{array}{c}0.0031 \\
(0.0038)\end{array}$ & $\begin{array}{c}0.0060 \\
(0.0036)\end{array}$ \\
\hline $\begin{array}{l}\text { Independent commission } \\
\text { indicator variable }\end{array}$ & - & - & - & $\begin{array}{c}-0.0132^{*} \\
(0.0060)\end{array}$ & $\begin{array}{l}-0.0138^{*} \\
(0.0066)\end{array}$ & $\begin{array}{r}-0.0172^{* *} \\
(0.0043)\end{array}$ \\
\hline $\begin{array}{l}\text { Other commission } \\
\text { indicator variable }\end{array}$ & - & - & - & $\begin{array}{c}0.0172 \\
(0.0113)\end{array}$ & $\begin{array}{c}0.0194 \\
(0.0119)\end{array}$ & $\begin{array}{c}0.0071 \\
(0.0040)\end{array}$ \\
\hline Number of observations & 2568 & 2344 & 1852 & 2568 & 2344 & 1852 \\
\hline Number of states & 43 & 31 & 19 & 43 & 31 & 19 \\
\hline
\end{tabular}

${ }^{*}, * *$ - Statistically significant at the $5 \%$ and $1 \%$ levels respectively. 
The last three specifications include the redistricting indicator variables. For these three models, note first that the coefficients on the SNPV and the preclearance indicator are of the same signs and magnitudes as the coefficient estimates in the first three models and also remain statistically significant at conventional levels. Note next that the coefficient on all the redistricting indicator variables with the exception of the indicator for independent redistricting commissions are statistically insignificant at conventional levels. This implies that there is no competitive difference between elections that use these redistricting methods and elections based on partisan legislative redistricting, which is the excluded category. This is a surprising result as it suggests that gerrymandering is no more likely under partisan redistricting than under these other methods.

Finally, and most importantly, note that the coefficient on the indicator variable for independent redistricting commissions is negative and statistically significant at conventional levels in all three model specifications for which it is included. The magnitude of this coefficient indicates that the presence of an independent redistricting commission reduces the DNPV by between 1.3 and 1.7 percentage points compared with the average DNPV of a little more than 12 percentage points. This is a modest effect but it must be remembered that the value of the DNPV is driven primarily by the degree of political partisanship within a state (i.e. by the SNPV), something that redistricting of any kind cannot effect. It is also worth pointing out that the coefficient on the independent commission indicator variable becomes more negative as the minimum number of districts increases, implying that the pro-competitive effect of independent commissions becomes stronger as the scope for gerrymandering rises.

Table 3 contains the results from fixed-effect regression analysis when data from just the last four presidential elections is used rather than data from the last six elections (that is, data from the last two redistricting cycles rather than the last three cycles.) The results of this analysis essentially duplicate the results from the full sample except that they show the coefficient on the independent commission indicator variable becoming even more negative, indicating that the pro-competitive effect from these commissions has grown stronger in more recent elections.

\section{Conclusion}

The results of this paper demonstrate two important points. First, there is clear evidence that US House elections have become increasingly less competitive over the last two decades. Mean victory margins have increased, the percentage of competitive districts has declined and the percentage of safe districts has increased. Depending on how these effects are measured, they vary from modest to substantial but there is no doubt that they are occurring. Second, there is also clear evidence that the introduction of independent redistricting commissions can moderate this trend. The results of the paper show that the presence of an independent redistricting commission reduces the mean victory margin by between 1.3 and 2.1 percentage points, relative to a mean victory margin of 12 
Table 3. Regression results for 2004-2016 presidential elections (clustered standard errors in parentheses, state and year fixed effects suppressed).

\begin{tabular}{|c|c|c|c|c|c|c|}
\hline & Model 1 & Model 2 & Model 3 & Model 4 & Model 5 & Model 6 \\
\hline $\begin{array}{l}\text { State normalized } \\
\text { presidential vote } \\
\text { (SNPV) }\end{array}$ & $\begin{array}{l}0.3609^{* *} \\
(0.0927)\end{array}$ & $\begin{array}{l}0.3491^{\star *} \\
(0.0984)\end{array}$ & $\begin{array}{l}0.4058^{\star *} \\
(0.1098)\end{array}$ & $\begin{array}{l}0.3651^{\star *} \\
(0.0949)\end{array}$ & $\begin{array}{l}0.3536^{\star *} \\
(0.1009)\end{array}$ & $\begin{array}{l}0.4130^{\star *} \\
(0.1126)\end{array}$ \\
\hline $\begin{array}{c}\text { Preclearance indicator } \\
\text { variable }\end{array}$ & $\begin{array}{l}0.0161^{\star *} \\
(0.0054)\end{array}$ & $\begin{array}{l}0.0186^{\star *} \\
(0.0057)\end{array}$ & $\begin{array}{l}0.0169^{*} \\
(0.0066)\end{array}$ & $\begin{array}{l}0.0154^{*} \\
(0.0067)\end{array}$ & $\begin{array}{l}0.0182^{* *} \\
(0.0066)\end{array}$ & $\begin{array}{l}0.0183^{*} \\
(0.0073)\end{array}$ \\
\hline $\begin{array}{l}\text { Bipartisan legislative } \\
\text { indicator variable }\end{array}$ & - & - & - & $\begin{array}{l}-0.0090 \\
(0.0056)\end{array}$ & $\begin{array}{l}-0.0091 \\
(0.0062)\end{array}$ & $\begin{array}{l}-0.0060 \\
(0.0092)\end{array}$ \\
\hline $\begin{array}{l}\text { Judicial indicator } \\
\text { variable }\end{array}$ & - & - & - & $\begin{array}{l}-0.0058 \\
(0.0037)\end{array}$ & $\begin{array}{l}-0.0050 \\
(0.0039)\end{array}$ & $\begin{array}{l}-0.0056 \\
(0.0054)\end{array}$ \\
\hline $\begin{array}{c}\text { Independent } \\
\text { commission indicator } \\
\text { variable }\end{array}$ & - & - & - & $\begin{array}{c}-0.0165^{* *} \\
(0.0040)\end{array}$ & $\begin{array}{c}-0.0171^{* *} \\
(0.0045)\end{array}$ & $\begin{array}{c}-0.0213^{\star *} \\
(0.0055)\end{array}$ \\
\hline $\begin{array}{l}\text { Other commission } \\
\text { indicator variable }\end{array}$ & - & - & - & $\begin{array}{c}0.0073 \\
(0.0070)\end{array}$ & $\begin{array}{c}0.0086 \\
(0.0074)\end{array}$ & $\begin{array}{c}0.0042 \\
(0.0043)\end{array}$ \\
\hline $\begin{array}{l}\text { Number of } \\
\text { observations }\end{array}$ & 1712 & 1552 & 1222 & 1712 & 1552 & 1222 \\
\hline Number of states & 43 & 30 & 18 & 43 & 30 & 18 \\
\hline
\end{tabular}

*,** - Statistically significant at the $5 \%$, and $1 \%$ levels, respectively.

percentage points for the entire sample. This pro-competitive effect increases the larger the number of congressional districts in a state and the more recent the election.

While the pro-competitive effect of independent redistricting commissions is not large, it is hardly insignificant, especially when one accounts for the high degree of partisanship in many states. In these states, the electorate is disproportionately Republican or Democratic, implying that elections will remain uncompetitive no matter how redistricting is carried out. Such states are much less susceptible to gerrymandering and consequently there is no real need for independent redistricting commission in them. The states that are most susceptible to gerrymandering are those where there is potentially greater competitive balance but that balance is threatened by gerrymandering. In these states, the presence of an independent redistricting commission can block a gerrymander and yield meaningfully more competitive outcomes in the process.

It is worth emphasizing that independent redistricting commissions also have benefits that go beyond their pro-competitive effect. For example, they may reduce the burden on the judicial system resulting from protracted court cases involving gerrymandered districts, such as the cases mentioned in the introduction to this paper. They may also lead to greater transparency and accountability, thereby increasing citizen confidence and trust in government. If so, they could enhance election turnout, which is relatively low in the United States compared to most other industrialized democracies. 
Independent redistricting commissions are not a cure all for what ails the American electoral process but they are a step in the right direction. Other electoral reforms are also worth considering and these reforms may be more appropriate than redistricting commissions for some states. The important point is that there are viable options for reforming the US electoral process in ways that can enhance its credibility and legitimacy.

\section{Conflicts of Interest}

The author declares no conflicts of interest regarding the publication of this paper.

\section{References}

Abramowitz, A. I., Alexander, B., \& Gunning, M. (2006). Incumbency, Redistricting, and the Decline of Competition in U.S. House Elections. The Journal of Politics, 68, 75-88. https://doi.org/10.1111/j.1468-2508.2006.00371.x

Besley, T., \& Preston, I. (2007). Electoral Bias and Policy Choice: Theory and Evidence. The Quarterly Journal of Economics, 122, 1473-1510. https://doi.org/10.1162/qjec.2007.122.4.1473

Bracco, E. (2013). Optimal Districting with Endogenous Party Platforms. Journal of Public Economics, 104, 1-13. https://doi.org/10.1016/j.jpubeco.2013.04.008

Cain, B. E. (2012). Redistricting Commissions: A Better Political Buffer? Yale Law Journal, 121, 1808-1844.

Carson, J. L., \& Crespin, M. H. (2004). The Effect of State Redistricting Methods on Electoral Competition in United States House of Representatives Races. State Politics and Policy Quarterly, 4, 455-469. https://doi.org/10.1177/153244000400400406

Carson, J. L., Crespin, M. H., \& Williamson, R. D. (2014). Reevaluating the Effects of Redistricting on Electoral Competition, 1972-2012. State Politics and Policy Quarterly, 14, 165-177. https://doi.org/10.1177/1532440013520245

Chen, J., \& Rodden, J. (2013). Unintentional Gerrymandering: Political Geography and Electoral Bias in Legislatures. Quarterly Journal of Political Science, 8, 239-269. https://doi.org/10.1561/100.00012033

Coate, S., \& Knight, B. (2007). Socially Optimal Redistricting: A Theoretical and Empirical Exploration. Quarterly Journal of Economics, 122, 1409-1471. https://doi.org/10.1162/qjec.2007.122.4.1409

Cottrill, J. B., \& Peretti, T. J. (2013). Gerrymandering from the Bench? The Electoral Consequences of Judicial Redistricting. Election Law Journal: Rules, Politics, and Policy 12, 261-276. https://doi.org/10.1089/elj.2012.0176

Friedman, J. N., \& Holden, R. T. (2008). Optimal Gerrymandering: Sometimes Pack but Never Crack. The American Economic Review, 98, 113-144.

https://doi.org/10.1257/aer.98.1.113

Jacobson, G. C. (2013). The Politics of Congressional Elections (8th ed.). New Haven: Yale University Press.

Lublin, D., \& McDonald, M. P. (2006). Is It Time to Draw the Line? The Impact of Redistricting on State House Elections. Election Law Journal, 5, 144-157.

https://doi.org/10.1089/elj.2006.5.144

Mann, T. E. (2016). We Must Address Gerrymandering. 
http://time.com/collection-post/4527291/2016-election-gerrymandering/

Maskett, S. E., Winburn, J., \& Wright, G. C. (2012). The Gerrymanders Are Coming! Legislative Redistricting Won't Affect Competition or Polarization Much, No Matter Who Does It. PS: Political Science \& Politics, 45, 39-43. https://doi.org/10.1017/S1049096511001703

McDonald, M. P. (2004). A Comparative Analysis of Redistricting Institutions in the United States, 2001-02. State Politics and Policy Quarterly, 4, 371-395. https://doi.org/10.1177/153244000400400402

McDonald, M. P. (2006). Drawing the Line on District Competition. PS: Political Science \& Politics, 39, 91-94. https://doi.org/10.1017/S1049096506060161

Owen, G., \& Grofman, B. (1988). Optimal Partisan Gerrymandering. Political Geography Quarterly, 7, 5-22. https://doi.org/10.1016/0260-9827(88)90032-8

Sherstyuk, K. (1998). How to Gerrymander: A Formal Analysis. Public Choice, 95, 27-49. https://doi.org/10.1023/A:1004986314885

Winburn, J. (2011). Does It Matter If Legislatures or Commissions Draw the Lines? In G. Moncrief (Ed.), Reapportionment and Redistricting in the West (pp. 137-160). Lanham, MD: Lexington Books.

Yoshinaka, A., \& Murphy, C. (2011). The Paradox of Redistricting: How Partisan Mapmakers Foster Competition but Disrupt Representation. Political Research Quarterly, 64, 435-447. https://doi.org/10.1177/1065912909355716

Washington, E. L. (2011). Do Majority Black Districts Limit Blacks' Representation? The Case of the 1990 Redistricting (Working Paper No. 17099). National Bureau of Economic Research. 
Appendix: Redistricting Method by State and Redistricting Cycle

\begin{tabular}{|c|c|c|c|}
\hline State & $1992-2000$ & $2002-2010$ & $2012-2016$ \\
\hline Alabama & Judicial & Partisan legislative & Partisan legislative \\
\hline Arizona & Judicial & Independent commission & Independent commission \\
\hline Arkansas & Partisan legislative & Partisan legislative & Partisan legislative \\
\hline California & Judicial & Partisan legislative & Independent commission \\
\hline Colorado & Bipartisan legislative & Judicial & Judicial \\
\hline Connecticut & Backup commission & Backup commission & Judicial \\
\hline Florida & Judicial & Partisan legislative & Partisan legislative 2012-14, judicial 2016 \\
\hline Georgia & $\begin{array}{c}\text { Partisan legislative 1992-94, } \\
\text { judicial 1996-2000 }\end{array}$ & Partisan legislative & Partisan legislative \\
\hline Hawaii & Political commission & Political commission & Political commission \\
\hline Idaho & Bipartisan legislative & Independent commission & Independent commission \\
\hline Illinois & Judicial & Bipartisan legislative & Partisan legislative \\
\hline Indiana & Backup commission & Backup commission & Partisan legislative \\
\hline Iowa & Advisory commission & Advisory commission & Advisory commission \\
\hline Kansas & Judicial & Partisan legislative & Judicial \\
\hline Kentucky & Partisan legislative & Bipartisan legislative & Bipartisan legislative \\
\hline Louisiana & $\begin{array}{c}\text { Bipartisan legislative 1992-94, } \\
\text { judicial 1996-2000 }\end{array}$ & Bipartisan legislative & Partisan legislative \\
\hline Maine & $\begin{array}{l}\text { Bipartisan legislative 1992, } \\
\text { judicial 1994-2000 }\end{array}$ & Judicial & Advisory commission \\
\hline Maryland & Partisan legislative & Partisan legislative & Partisan legislative \\
\hline Massachusetts & Bipartisan legislative & Partisan legislative & Partisan legislative \\
\hline Michigan & Judicial & Partisan legislative & Partisan legislative \\
\hline Minnesota & Judicial & Judicial & Judicial \\
\hline Mississippi & Partisan legislative & Judicial & Judicial \\
\hline Missouri & Bipartisan legislative & Bipartisan legislative & Partisan legislative \\
\hline Nebraska & Bipartisan legislative & Partisan legislative & Partisan legislative \\
\hline Nevada & Partisan legislative & Bipartisan legislative & Judicial \\
\hline New Hampshire & Partisan legislative & Bipartisan legislative & Partisan legislative \\
\hline New Jersey & Political commission & Political commission & Political commission \\
\hline New Mexico & Partisan legislative & Judicial & Judicial \\
\hline New York & $\begin{array}{l}\text { Judicial 1992-1996, bipartisan } \\
\text { legislative/judicial 1998-2000 }\end{array}$ & Bipartisan legislative & Judicial \\
\hline North Carolina & Bipartisan legislative & Partisan legislative & Partisan legislative \\
\hline Ohio & Bipartisan legislative & Partisan legislative & Partisan legislative \\
\hline Oklahoma & Partisan legislative & Judicial & Partisan legislative \\
\hline Oregon & Judicial & Judicial & Bipartisan legislative \\
\hline
\end{tabular}




\section{Continued}

\begin{tabular}{cccc}
\hline Pennsylvania & Judicial & Partisan legislative & Partisan legislative \\
Rhode Island & Partisan legislative & Partisan legislative & Advisory commission \\
South Carolina & Judicial & Judicial & Partisan legislative \\
Tennessee & Partisan legislative & Bipartisan legislative & Partisan legislative \\
Texas & Partisan legislative 1992-94, & Judicial 2002, partisan legislative 2004, & Judicial 2012, \\
partisan legislative/judicial 1996-2000 & partisan legislative/judicial 2006-10 & partisan legislative 2014-16 \\
Utah & Partisan legislative & Partisan legislative & Partisan legislative \\
Virginia & Partisan legislative 1992-96, & Partisan legislative & Partisan legislative 2012-14, \\
Washington & Bipartisan legislative 1998-2000 & Partisan legislative/judicial 2016 \\
West Virginia & Partisan legislative & Independent commission & Independent commission \\
Wisconsin & Bipartisan legislative & Partisan legislative & Partisan legislative
\end{tabular}

